\title{
KAJIAN KETERSEDIAAN AIR PERMUKAAN PADA BEBERAPA DAERAH ALIRAN SUNGAI \\ (Studi Kasus di Sub DAS Temon, Wuryantoro, Alang, dan Keduang)
}

\author{
Ugro Hari Murtiono \\ Kelompok Peneliti Konservasi Tanah dan Air (KTA) \\ Balai Penelitian Kehutanan (BPK) Solo \\ Jl. Ahmad Yani Pabelan, Po. Box. 295, Surakarta, Jawa Tengah, Telp/Fax: 0271-716709 \\ E-mail: ugrohm@yahoo.com
}

\begin{abstract}
The study was conducted at some watersheds (Temon, Wuryantoro, Alang, and Keduang sub Watersheds), in Wonogiri District. These four sub Watersheds are main river whose outlets go into Wonogiri Dam. The study will calculate of water availability and the need of water for various uses at four sub Watersheds. The Thornwaite and Mather method was used to calculate the of water availability. The results indicate that: (1) The water availability at Temon Sub Watershed) $35.435 .875 \mathrm{~m}^{3}$ and the need of water per year sebesar 51.053.247 $\mathrm{m}^{3}$, the water minus 30,59\% per year; (2) The water availability per year Wuryantoro sub Watershed $17.788 .417 \mathrm{~m}^{3}$ and the need of water per year $22.413 .430 \mathrm{~m}^{3}$, the water minus 20,64\% per year; (3) The water availability per year at Alang sub Watershed $31.372 .317 \mathrm{~m}^{3}$ per year and the need of water per year $69.566 .500 \mathrm{~m}^{3}$, the water minus $54,90 \%$ per year; (4) The water availability per year geological at Keduang sub Watershed 438.527 .889 $\mathrm{m}^{3}$ and the need of water per year $452.611 .219 \mathrm{~m}^{3}$, the water minus 3,11\% per year; (5). Watershed having condition needs improvement especially an effective water resourcesplan, allocating, and distributing of water according to priority establishment, e.g., water pond, revegetation with low evapotranspiration potential, developing infiltration well, protecting water spring from disconcerting, and construction of water reservoir.
\end{abstract}

Keywords: potency of water, need of water, and minus water

\section{PENDAHULUAN}

Sebagai salah satu sumber alam, air merupakan faktor amat penting dan mutlak untuk sumber kehidupan. Seperti telah diketahui dalam daur hidrologi, air mempunyai mobilitas yang tinggi. Melalui presipitasi, evaporasi, transpirasi, dan pengaliran, air berputar terus sepanjang masa. Jumlah penduduk yang semakin bertambah, meningkatnya kebutuhan pangan, bertambahnya luas sawah dan industri yang juga diikuti teknologi semakin berkembang dapat menyebabkan keadaan air relatif dirasakan semakin berkurang baik kuantitas ataupun kualitasnya. Meskipun air di bumi ini tetap, yang berbeda adalah sifat penyebarannya yang tidak merata baik menurut lokasi geografi ataupun waktu (Soewarno dan Srimulat Yuningsih, 2000). 
Pengelolaan DAS adalah serangkaian kegiatan dengan berbagai cara yang saling terkait dengan penuh pertimbangan untuk mencapai suatu tujuan (Pusposutarjo, 1989). Tujuan pengelolaan DAS untuk mencapai kelestarian DAS agar dapat memberikan manfaat yang maksimal dan berkesinambungan bagi kesejahteraan manusia. Tujuan pengelolaan DAS dapat dicapai maka sasaran pengelolaan DAS meliputi berbagai aspek yaitu pengelolaan ekosistem, pengelolaan lahan, pengelolaan air dan pengelolaan sumber daya manusia.

Proses hidrologi dalam suatu DAS secara sederhana dapat digambarkan dengan adanya hubungan antara unsur masukan yakni hujan, proses dan keluaran yaitu berupa aliran. Hujan akan menghasilkan aliran tertentu pula dan aliran ini selain dipengaruhi oleh karakteristik DAS dan juga sangat tergantung pada karakteristik hujan yang jatuh. Karakteristik hujan meliputi tebal hujan, intensitas hujan dan durasi hujan, sedang karakteristik DAS meliputi topografi, geologi, geomorfologi, tanah, penutup lahan/vegetasi, dan pengolahan lahan serta morfometri DAS (Hadi, 2006).

Pengelolaan air diperlukan untuk memberikan kemakmuran dan kesejahteraan kepada masyarakat, sehingga perlu diketahui persediaan dan kebutuhan air dalam suatu daerah. Walaupun air terdapat dimana-mana, namun kuantitasnya terbatas, begitu pula tersedianya menurut waktu dan letak geografisnya, kualitasnyapun sering tidak sesuai dengan keperluan, oleh karena itu tanpa adanya usaha-usaha manusia, sedikit atau banyak tidaklah mungkin untuk memanfaatkan air guna kemakmuran serta kesejahteraannya menurut jumlah, selera, waktu dan lokasi yang dikehendaki.

Pada waktu dahulu sebelum air diperlukan untuk berbagai keperluan dan dalam jumlah yang besar, air itu relatif masih belum merupakan suatu masalah, karena masih dapat memenuhi keperluan masyarakat. Masa kini, sangat dirasakan bahwa jenis serta banyaknya kebutuhan akan air begitu meningkat, sehingga harus dapat kita atur sedemikian rupa, agar supaya semua keperluan dalam berbagai bidang dan dalam waktu, tempat serta jumlah tertentu, baik untuk keperluan ekonomi maupun usaha-usaha sosial dan budaya, dapat dipenuhi secara baik, teratur serta lestari.

Pengelolaan DAS harus terus dievaluasi, salah satu parameternya adalah persediaan air untuk mengetahui kondisi DAS apakah dalam kondisi buruk, sedang dan baik. Perhitungan nilai persediaan air tersebut perlu diketahui berapa potensi (ketersediaan air) yang kemudian dibandingkan dengan kebutuhan air yang diperlukan baik untuk air minum daerah pemukiman maupun untuk keperluan pola penggunaan lahan yang diterapkan pada DAS. Tujuan penelitian ini adalah mengkaji ketersediaan dan pemanfaatan air permukaan sub DAS Temon, Wurantoro, Alang, dan Keduang di Daerah Aliran Sungai (DAS) Solo Hulu.

\section{METODE PENELITIAN}

\section{Lokasi}

Kegiatan penelitian dilaksanakan pada empat sub DAS. Secara administrasi termasuk dalam wilayah Kabupaten Wonogiri. Masing-masing sub DAS terletak 
Tabel 1. Lokasi, Letak lintang, Formasi Geologi dan Luas DAS

\begin{tabular}{|c|c|c|c|}
\hline Sub DAS & Letak Lintang & Formasi Geologi & Luas (ha) \\
\hline Temon & $\begin{array}{l}7^{0} 49^{\prime} 48,24^{\prime \prime}-7^{0} 52^{\prime} 51,89^{\prime \prime} \mathrm{LS} \\
110^{0} 49^{\prime} 56,70^{\prime \prime}-110^{0} 52^{\prime} 38,50^{\prime \prime} \text { BT }\end{array}$ & $\begin{array}{l}\text { Campuran Volkan } \\
\text { Tua-Kapur }\end{array}$ & 4.250 \\
\hline Wuryantoro & $\begin{array}{l}7^{0} 49^{\prime} 48,24^{\prime \prime}-7^{0} 52^{\prime} 38,5^{\prime \prime} \text { LS } \\
110^{0} 49^{\prime} 56,70^{\prime \prime}-110^{0} 52^{\prime} 38,50^{\prime \prime} \text { BT }\end{array}$ & $\begin{array}{l}\text { Campuran Volkan } \\
\text { Tua-Kapur }\end{array}$ & 1.792 \\
\hline Alang & $\begin{array}{l}8^{0} 01^{\prime} 49^{\prime \prime}-8^{0} 06^{\prime} 06^{\prime \prime} \mathrm{LS} \\
110^{0} 46^{\prime} 49,7^{\prime \prime}-110^{0} 54^{\prime} 10,7^{\prime \prime} \text { BT }\end{array}$ & Kapur & 5.439 \\
\hline Keduang & $\begin{array}{l}7^{0} 42^{\prime} 27,16^{\prime \prime}-7^{0} 55^{\prime} 35,51^{\prime \prime} \text { LS } \\
110^{0} 59^{\prime} 29,29^{\prime \prime}-111^{0} 13^{\prime} 30,00^{\prime \prime} \text { BT }\end{array}$ & Volkan muda & 35.993 \\
\hline
\end{tabular}

Sumber: Peta Rupa Bumi Indonesia (RBI) Skala 1: 25.000

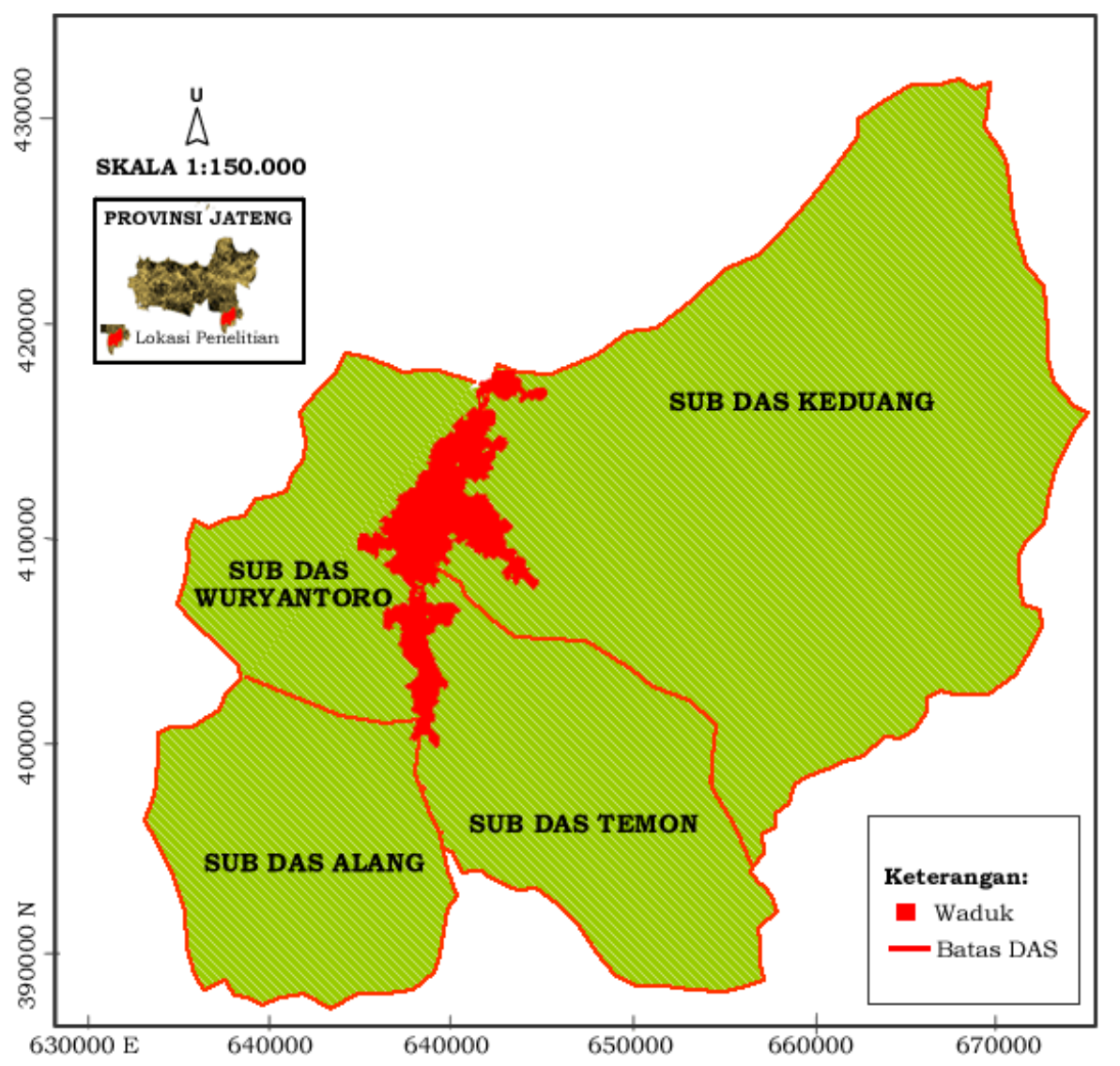

Sumber: Peta Rupa Bumi Indonesia (RBI) Skala 1: 25.000

Gambar 1. Lokasi Sub DAS Temon, Wuryantoro, Alang dan Keduang 
di Kecamatan Baturetno (sub DAS Temon). Kecamatan Pracimantoro dan Giritontro (sub DAS Alang), Kecamatan Wuryantoro (sub DAS Wuryantoro), dan Kecamatan Ngadirojo, Nguntoronadi, dan Slogohimo (sub DAS Keduang). Lokasi ini dipilih karena: (1) Keempat sungai tersebut merupakan sungai utama yang masuk ke waduk wonogiri yang sekarang ini mempunyai masalah sedimentasi yang cukup tinggi; (2) Keempat lokasi tersebut masing-masing mempunyai masalah kekurangan air yang cukup ekstrim dan; (3) Keempat lokasi masing masing mempunyai formasi geologi yang berbeda yaitu campuran volkan tua dan kapur di sub DAS Temon dan Wuryantoro, kapur di sub DAS Alang, dan volkan muda di sub DAS Keduang. Letak lintang-bujur dan luas masing-masing sub DAS disajikan pada Tabel 1.

\section{Iklim}

Menurut klasifikasi Koppen, daerah penelitian beriklim hujan tropik (A) dengan tipe Awa dan Ama. Tipe iklim Awa terdapat di sub DAS Temon dan Alang, tipe iklim Ama terdapat pada sub DAS Wuryantoro, tipe iklim di sub DAS Keduang adalah D, musim hujan terjadi antara bulan November - April, sedangkan musim kering pada bulan Mei - Oktober, jumlah bulan basah 6-7 bulan (Schmidt dan Ferguson, 1951).

\section{Geologi dan Geomorfologi}

Berdasarkan Peta Geologi Bersistem Indonesia Lembar Surakarta 1408-03, Lembar Giritontro 1407-6, Lembar Pacitan 1507-4 Tahun 1992 skala 1:100.000, lembar Ponorogo 1508-1 tahun 1997 skala 1 : 100.000 dan Peta Geologi Jawa dan
Madura Lembar III Jawa Timur tahun 1963 skala $1: 500.000$, berikut diskripsi singkat mengenai kondisi geologi dan geomorfologi daerah penelitian.

\section{Sub DAS Temon}

Terdiri dari 4 (empat) formasi geologi yaitu: Semilir, formasi Wonosari - Punung, formasi Mandalika, dan formasi Nglanggran. Fomasi Semilir berumur miosen awal berupa tuf, breksi, batuapung dasitan, batu pasir tufan dan serpih. Formasi Wonosari-Punung berumur dari miosen tengah hingga pliosen, yang berupa batu gamping napalan-tufan, batu gamping konglomerat, batu gamping tufan dan batu lanau. Formasi Mandalika berumur miosen awal yang berupa lava dasit-andesit dan tufa dasit dengan retas diorit, serta formasi Nglanggran yang berumur miosen awal hingga miosen tengah yang berupa breksi gunung api aglomerat dan lava andesit basal dan tuff.

\section{Sub DAS Wuryantoro}

Sub DAS Wuryantoro merupakan formasi Oyo terdiri dari andesit hornblende, batu pasir tuf, tuf vitreous, napal tufan dan tanah liat (clay). Di formasi ini juga dijumpai breksi dari kapur (limestone breccias) dan konglomerat dari batu kapur (conglomeratic limestone). formasi andesit tua dijumpai pada sub DAS Wuryantoro bagian hulu, pada formasi ini terdapat 2 (dua) igir yaitu Igir Plopoh dan Igir Kembengan, kedua igir mempunyai batuan yang resisten yaitu tuff dan batuan andesit tua dari endapan gunung berapi tua pada jaman miosen tua. Berkaitan dengan kondisi iklim dan geologinya, proses-proses geomorfologi yang penting di daerah 
Tabel 2. Luas Penggunaan Lahan pada Daerah Penelitian (ha)

\begin{tabular}{lrrrrrrrr}
\hline \hline \multirow{2}{*}{ Sub DAS } & \multicolumn{2}{c}{ Tegal } & \multicolumn{2}{c}{ Sawah } & \multicolumn{2}{c}{ Kampung } & \multicolumn{2}{c}{ Hutan } \\
\cline { 2 - 10 } & (ha) & \multicolumn{1}{c}{$\%$} & (ha) & \% & (ha) & \multicolumn{1}{c}{$\%$} & (ha) & \multicolumn{1}{c}{$\%$} \\
\hline \multirow{2}{*}{ Temon } & 1.446 & 34,00 & 942 & 22,20 & 805 & 18,90 & 1.057 & 24,90 \\
Wuryantoro & 1.035 & 57,76 & 238 & 13,28 & 305 & 17,02 & 214 & 11,94 \\
Alang & 3.284 & 60,50 & 686 & 12,63 & 1.145 & 21,09 & 314 & 5,78 \\
Keduang & 17.210 & 47,81 & 11.798 & 32,78 & 4.424 & 12,29 & 2.561 & 7,12 \\
\hline
\end{tabular}

Sumber: - Peta Rupa Bumi Indonesia (RBI) Skala 1: 25.000

- Hasil Perhitungan

penelitian antara lain pelapukan, erosi, dan sedimentasi. Suhu udara yang selalu tinggi mempengaruhi laju pelapukan batuan, namun demikian pembentukan tanah terhambat oleh proses erosi terutama didaerah hulu. Pada sub DAS Wuryantoro tingkat erosinya sudah sangat lanjut sehingga sedimen yang terangkut sungai relatif kecil.

\section{Sub DAS Alang}

Sub DAS Alang merupakan formasi Kepek menempati daerah terluas, terdiri batu napal (marls) dan batu karang. Batu napal adalah sedimen yang terdiri dari bahan kalsium karbonat $\left(\mathrm{CaCo}^{3}\right)$ dengan lempung ataupun lanau. Di sebelah hulu formasi Kepek dijumpai formasi Wonosari yang berbatuan gamping.

\section{Sub DAS Keduang}

Sub DAS Keduang merupakan formasi Blitar sub Zone menempati daerah yang dominan luas, terdiri dari batuan breksi Notopuro dan vulkanik muda dan sebelah selatan berbatasan dengan igir Kambengan (Kambengan Range). Di sebelah barat adalah dataran alluvial yang berbatasan dengan igir Plopoh (Plopoh Range).

\section{Penggunaan Lahan}

Penggunaan lahan di daerah penelitian terdiri dari tegal, sawah, kampung, dan hutan. Lahan tegalan menempati wilayah terluas. Sawah yang dikerjakan masyarakat berupa sawah tadah hujan, perkampungan yang ada umumnya berupa desa, lahan hutan di empat sub DAS relatif sedikit, terluas di sub DAS Temon hanya 24,9\%. Luas masing-masing penggunaan lahan disajikan pada Tabel 2.

\section{Tanah}

Daerah penelitian mempunyai tiga kelompok tanah utama (main soil group) yaitu laterit, margalit dan tanah kapur. Jenis laterit yang ada bersifat andesitik dengan warna merah. Jenis tanah ini mempunyai permeabilitas dan kapasitas menahan air cukup baik. Pada daerah yang tinggi atau lereng curam, erosi berlangsung cepat, sehingga lapisan tanah sangat tipis dan 
banyak dijumpai singkapan. jenis tanah ini terdapat di sub DAS Temon dan Wuryantoro bagian hulu.

Jenis margalit yang dijumpai ada 2 (dua) macam yaitu margalit hitam dan margalit andesitik hitam. Jenis tanah margalit hitam mempunyai sifat lekat kalau basah, plastisitas sedang dan berupa blokblok yang keras bila mengering. Penyebaran tanah ini berada didaerah berbukit dan umumnya mempunyai solum dangkal. jenis tanah margalit hitam mempunyai tekstur sangat halus, terbentuk dari material pasir, loam dan clay. Material clay mendominasi tanah ini dengan kandungan $70 \%$, dan tanah margalit andesitik hitam juga kaya akan kapur (Dames, 1955).

Jenis tanah kapur yang dijumpai di sub DAS Alang bersifat laterik berwarna merah sampai coklat hitam. Jenis tanah ini mengandung lebih dari $97 \%$ mineral $\mathrm{CaCo}^{3}$, bersifat agak plastis dan lengket, permeabilitas lambat dan cukup menahan air . Pada saat kering tanah menjadi retak membentuk blok-blok yang keras. Sebagian besar solumnya dangkal. Kedalamannya bervariasi dari nol pada lereng curam hingga beberapa meter pada lembah.

\section{Air permukaan yang tersedia}

Perhitungan air permukaan yang tersedia digunakan metode ThornthwaiteMather. Berdasarkan pada ketersediaan data yang ada di lokasi penelitian yaitu data temperatur udara bulanan untuk menghitung evapotranspirasi potensial, curah hujan rata-rata, penggunaan lahan dan jenis tanah untuk perhitungan "Water Holding Capasity", dan metode ini merupakan metode yang cukup baik karena parameter-parameter yang digunakan cukup mewakili untuk memperhitungkan air permukaan yang tersedia.

\section{Hujan}

Dalam perhitungan air permukaan yang tersedia dengan menggunakan metode Thornthwaite - Mather memerlukan data curah hujan yang berkesinambungan. Daerah penelitian sudah tersedia data curah hujan yang diamati oleh Balai Penelitian Kehutanan (BPK) Solo mulai tahun 1991 sampai tahun 2007.

\section{Temperatur udara}

Temperatur udara didaerah penelitian dihitung dengan menggunakan data temperatur di Stasiun Meteorologi Pabelan (106 m dpl) Proyek PWS Bengawan Solo dengan menggunakan pendekatan rumus (Mock, 1973)

$$
\mathrm{T}=0,006\left(\mathrm{H}-\mathrm{H}_{1}\right)^{\mathrm{O}} \mathrm{C}
$$

dimana:

$$
\begin{aligned}
\mathrm{T}= & \text { perbedaan temperatur } \\
\mathrm{H}= & \begin{array}{l}
\text { ketinggian dari stasiun setempat } \\
\text { (meter) }
\end{array} \\
\mathrm{H}_{1}= & \begin{array}{l}
\text { ketinggian rata-rata dari daerah } \\
\text { penelitian }
\end{array}
\end{aligned}
$$

\section{Perhitungan Evapotranpirasi Potensial Bulanan Sebelum Terkoreksi (EP*)}

Evapotranpirasi Potensial Bulanan Sebelum Terkoreksi (EP*) dihitung berdasarkan suhu udara, dengan rumus :

$$
\mathrm{EP} *=1,6^{\mathrm{a}} \frac{10 \mathrm{~T}}{\mathrm{I}}
$$




$$
\begin{aligned}
& I=\sum_{n=1}^{12} i \\
& \mathrm{i}=\frac{\mathrm{T}^{1,514}}{5} \\
& \mathrm{a}=0,000000675 \mathrm{I}^{3}-0,000077 \mathrm{I}^{2}+ \\
& 0,017921+0,49239 \text {. }
\end{aligned}
$$

\section{Perhitungan Evapotranspirasi Potensial (EP) Bulanan Setelah Terkoreksi}

Evapotranpirasi Potensial (EP) bulanan setelah terkoreksi dihitung dengan menggunakann rumus :

$$
\mathrm{Ep}=\mathrm{f} . \mathrm{EP}^{*}
$$

dimana:

$\mathrm{f}=$ adalah faktor koreksi yang diperoleh berdasar-kan letak lintang lokasi peneliti

\section{Hujan Bulanan dikurangi Evapo- transpirasi Potensial Bulanan Setelah Terkoreksi (P - EP)}

P - EP adalah selisih antara curah hujan dengan evapotranspirasi potensial. Nilai ini diperlukan untuk menentukan kelebihan dan kekurangan periode lembab atau basah, nilai negatif dari P - EP mengindikasikan bahwa jumlah curah hujan yang jatuh tidak mampu menambah kebutuhan potensi air dari areal yang tertutup vegetasi. Sedangkan nilai positif dari P - EP mengindikasikan bahwa jumlah kelebihan air yang tersedia selama periode tertentu dalam 1 tahun untuk mengembalikan kelembaban tanah dan aliran permukaan.

\section{Akumulasi Potensi Kehilangan Air (APWL)}

Akumulasi Potensi Kehilangan Air (APWL) diperlukan untuk mengetahui potensi kehilangan air pada bulan kering. Perhitungan nilai $A P W L$ didasarkan pada : nilai P - EP negatif, maka secara berurutan dijumlahkan dengan nilai P - EP sesudahnya sampai dengan P - EP negatif yang tesrakhir, sehingga penjumlahannya secara kumulatif.

\section{Perubahan Lengas Tanah ( D St )}

Nilai perubahan lengas tanah dihitung berdasarkan selisih antara cadangan lengas tanah bulan sebelumnya dengan cadangan lengas tanah bulan ini.

\section{Evapotranspirasi Aktual (AE)}

Nilai Evapotranspirasi Aktual diperoleh dengan ketentuan :

1. Apabila $\mathrm{P}>\mathrm{EP}$ maka $\mathrm{AE}=\mathrm{EP}$

2. Apabila $\mathrm{P}<\mathrm{EP}$ maka $\mathrm{AE}=\mathrm{P}+\mathrm{D}$ ST

\section{Defisit}

Nilai defisit (D) diperoleh berdasarkan pada selisih antara EP - AE. 


\section{Surplus}

Nilai surplus (S) diperoleh berdasarkan rumus $\mathrm{S}=(\mathrm{P}-\mathrm{EP})-\mathrm{D} \mathrm{ST}$

\section{Air permukaan yang tersedia}

Air permukaan yang tersedia diperoleh dari surplus air yang besarnya diasumsikan 50\% dan sisanya akan keluar menjadi aliran pada bulan berikutnya.

\section{Kebutuhan Air}

Kebutuhan air dihitung berdasarkan dominasi penggunaan lahan yang ada di lokasi penelitian yaitu:

1. Tegal yang terdiri dari kebutuhan air untuk tanaman tahunan dan musiman

2. Sawah yang terdiri dari1 kali panen, 2 kali panen, 5 kali panen 2 tahun

3. Pemukiman

4. Hutan

\section{Tegal}

Komposisi tanaman di lahan tegal pada umumnya adalah kacang tanah, jagung, dan singkong. Kacang tanah dan jagung biasanya dapat dua kali panen (musim tanam I dan II). Pada musim tanam III biasanya hanya tanaman singkong yang ada. Kebutuhan air pada komposisi jenis tanam yang demikian diperkirakan sebesar $1200 \mathrm{~mm} /$ tahun (Dumairi, 1992).

\section{Sawah}

Kebutuhan air untuk sawah irigasi ditetapkan 1 liter/detik/ha. Angka ini bila dikonversi dalam mm menjadi $1200 \mathrm{~mm} /$ tahun, jika sawah tersebut hanya sekali panen dalam satu tahun. Jika dua kali panen dalam satu tahun maka kebutuhan airnya menjadi $2400 \mathrm{~mm} /$ tahun. Jika pada lahan tersebut diselingi palawija ( 1 kali padi dan 1 kali palawija) maka kebutuhan airnya menjadi $2000 \mathrm{~mm} /$ th (Dumairi, 1992).

\section{Pemukiman/penduduk}

Dalam memenuhi kebutuhan air minum kita dapat memanfaatkan berbagai jenis sumber yang dapat diklssifikasikan berasal dari sumber air tanah, air permukaan, air hujan maupun air laut. Variasi asal sumber yang digunakan dalam penggunaan air untuk kebutuhan rumah tangga akan juga menentukan perbedaan pola penggunaan air di daerah yang bersangkutan (Anna et al., 2000).

Kebutuhan air untuk penduduk di daerah penelitian diperkirakann $1200 \mathrm{~mm} /$ tahun. Angka ini diperoleh dengan asumsi kepadatan penduduk 700 jiwa $/ \mathrm{km}^{2}$. Keperluan tiap orang sebesar 80 liter/hari. Kepadatan ternak besar 40 ternak $/ \mathrm{km}^{2}$ membutuhkan air sebanyak 25 liter/hari/ ternak. Kepadatan ternak kecil 150 ternak $/ \mathrm{km}^{2}$ membutuhkan air sebanyak 5 liter/hari/ternak (Dumairi, 1992).

\section{Hutan}

Hutan yang berdaun lebar menurut Coster (1937) dalam Asdak (1995), mempunyai laju evapotranspirasi berkisar antara 800 - $1400 \mathrm{~mm} /$ tahun tergantung pada kondisi daerahnya. Untuk kondisi kesuburan tanah yang sedang maka laju evapotranspirasinya sekitar $1000 \mathrm{~mm} /$ tahun. Laju evapotranspirasi pada hutan alam di pegunungan berkisar antara 500 $1200 \mathrm{~mm} /$ tahun, tergantung elevasi 
daerah-nya. Makin tinggi elevasinya, laju evapotranspirasi makin berkurang. Untuk daerah dengan elevasi $+1000 \mathrm{~m}$ dpl, laju evapotranspirasinya sebesar $1200 \mathrm{~mm} /$ tahun. Sedangkan pada daerah dengan elevasi $+2500 \mathrm{~m} \mathrm{dpl}$, laju evapotranspirasinya berkisar antara $500-600 \mathrm{~mm} / \mathrm{th}$. Berdasarkan hal tersebut maka kebutuhan air untuk vegetasi hutan daun lebar adalah $1000 \mathrm{~mm} /$ tahun.

\section{Kebutuhan air pada berbagai penutupan lahan}

Kebutuhan air pada suatu daerah dapat diperkirakan berdasarkan perhitungan. Kebutuhan air ini sangat tergantung pada pola penggunaan lahannya. Penggunaan lahan untuk sawah membutuhkan air yang paling banyak, untuk awal penenaman diperlukan air yang relatif tinggi yaitu pada bulan Januari April tergantung pada penggunaan lahannya, sedangkan pada bulan selanjutnya Mei-Desember agak sedikit berkurang (perincian kebutuhan air bulanan pada masing-masing penggunaan lahan dapat dilihat pada Tabel 3.

\section{HASIL DAN PEMBAHASAN \\ PERSEDIAAN AIR PERMUKAAN}

Perhitungan persediaan air permukaan menggunakan metode Thornthwaite Mather dengan menggunakan data temperatur udara bulanan untuk menghitung evapotranspirasi potensial, curah hujan rata-rata, penggunaan lahan dan jenis tanah untuk perhitungan "Water Holding $C a$ pacity" (WHC) hasil perhitungan disajikan pada Tabel 4.

Tabel 3. Kebutuhan Air Bulanan (mm) Berdasarkan Pola Penggunaan Lahan

\begin{tabular}{|c|c|c|c|c|c|c|c|c|c|c|c|c|c|}
\hline $\begin{array}{c}\text { Jenis } \\
\text { Tanaman }\end{array}$ & Jan & Feb & Mar & Apr & Mei & Jun & Jul & Aug & Sep & Okt & Nov & Des & Jml \\
\hline $\begin{array}{l}\text { Hutan } \\
\text { lainnya }\end{array}$ & 88 & 81 & 90 & 88 & 88 & 79 & 74 & 73 & 75 & 87 & 85 & 92 & 1.000 \\
\hline $\begin{array}{l}\text { Sawah } \\
1 \mathrm{X} \text { panen }\end{array}$ & 264 & 115 & 39 & 38 & 38 & 34 & 32 & 32 & 33 & 38 & 255 & 276 & 1.200 \\
\hline $\begin{array}{l}\text { Sawah } \\
2 \mathrm{X} \text { panen }\end{array}$ & 264 & 243 & 270 & 264 & 264 & 115 & 108 & 106 & 110 & 125 & 255 & 276 & 2.400 \\
\hline $\begin{array}{l}\text { Sawah } \\
5 \mathrm{X} \text { pn 2th }\end{array}$ & 264 & 243 & 270 & 264 & 264 & 237 & 222 & 219 & 225 & 261 & 255 & 276 & 3.000 \\
\hline Tegal & 119 & 109 & 121 & 119 & 119 & 107 & 100 & 99 & 101 & 117 & 115 & 124 & 1.350 \\
\hline Pemukiman & 106 & 97 & 108 & 106 & 106 & 95 & 89 & 88 & 90 & 103 & 102 & 110 & 1.200 \\
\hline
\end{tabular}

Sumber : Dumairi,1992 
Tabel 4. Potensi dan Kebutuhan Air $\left(\mathrm{m}^{3}\right)$ di Sub DAS Temon, Wuryantoro, Alang, dan Keduang

\begin{tabular}{|c|c|c|c|c|c|c|}
\hline No & Bulan & Potensi & Kebutuhan & \% Potensi & $\begin{array}{l}\text { Kelebihan / } \\
\text { Kekurangan } \\
\end{array}$ & \multirow{2}{*}{$\begin{array}{c}\% \\
\text { Kelebihan } \\
\text { /Kekurangan }\end{array}$} \\
\hline (01) & $(02)$ & (03) & (04) & $(05)=(03) /(04)$ & $(06)=(03)-(04)$ & \\
\hline \multicolumn{7}{|c|}{ sub DAS Temon } \\
\hline 1 & Januari & 5.900 .901 & 5.991 .320 & 98.49 & -90.419 & $-1,51$ \\
\hline 2 & Februari & 8.080 .412 & 4.296 .365 & 188.08 & 3.784 .047 & 88,08 \\
\hline 3 & Maret & 8.010 .987 & 3.937 .412 & 203.46 & 4.073 .575 & 103,46 \\
\hline 4 & April & 5.697 .644 & 3.861 .835 & 147.54 & 1.835 .809 & 47,54 \\
\hline 5 & Mei & 2.848 .822 & 3.861 .835 & 73.77 & -1.013 .013 & $-26,23$ \\
\hline 6 & Juni & 1.418 .431 & 3.466 .987 & 40.91 & -2.048 .556 & $-59,09$ \\
\hline 7 & Juli & 709.215 & 3.245 .797 & 21.85 & -2.536 .582 & $-78,15$ \\
\hline 8 & Agustus & 354.608 & 3.212 .720 & 11.04 & -2.858 .112 & $-88,96$ \\
\hline 9 & September & 177.304 & 3.288 .297 & 5.39 & -3.110 .993 & $-94,61$ \\
\hline 10 & Oktober & 88.652 & 3.798 .207 & 2.33 & -3.709 .555 & $-97,67$ \\
\hline 11 & November & 44.326 & 5.841 .317 & 0.76 & -5.796 .991 & $-99,24$ \\
\hline 12 & Desember & 2.104 .573 & 6.251 .155 & 33.67 & -4.146 .582 & $-66,33$ \\
\hline & Jumlah & 35.435 .875 & 51.053 .247 & 69.41 & -15.617 .372 & $-30,59$ \\
\hline \multicolumn{7}{|c|}{ sub DAS Wuryantoro } \\
\hline 1 & Januari & 2.983 .304 & 2.378 .550 & 125,43 & 604.754 & 25,43 \\
\hline 2 & Februari & 3.922 .771 & 1.876 .150 & 209,09 & 2.046 .621 & 109,09 \\
\hline 3 & Maret & 3.689 .667 & 1.871 .960 & 197,10 & 1.817 .707 & 97,10 \\
\hline 4 & April & 2.405 .448 & 1.838 .410 & 130,84 & 567.038 & 30,84 \\
\hline 5 & Mei & 1.202 .724 & 1.651 .400 & 72,83 & -448.676 & $-27,17$ \\
\hline 6 & Juni & 601.362 & 1.544 .920 & 38,93 & -943.558 & $-61,07$ \\
\hline 7 & Juli & 300.681 & 1.529 .340 & 19,66 & -1.228 .659 & $-80,34$ \\
\hline 8 & Agustus & 150.340 & 1.562 .340 & 9,62 & -1.412 .000 & $-90,38$ \\
\hline 9 & September & 75.170 & 1.562 .890 & 4,81 & -1.487 .720 & $-95,19$ \\
\hline 10 & Oktober & 37.585 & 1.806 .340 & 2,08 & -1.768 .755 & $-97,92$ \\
\hline 11 & November & 908.760 & 2.311 .210 & 39,32 & -1.402 .450 & $-60,68$ \\
\hline 12 & Desember & 1.510 .605 & 2.479 .920 & 60,91 & -969.315 & $-39,09$ \\
\hline & Jumlah & 17.788 .417 & 22.413 .430 & 79,36 & -4.625 .013 & $-20,64$ \\
\hline \multicolumn{7}{|c|}{ sub DAS Alang } \\
\hline 1 & Januari & 3.552 .381 & 7.222 .810 & 49,18 & -3.670 .429 & $-50,82$ \\
\hline 2 & Februari & 4.246 .432 & 5.743 .550 & 73,93 & -1.497 .118 & $-26,07$ \\
\hline 3 & Maret & 11.792 .534 & 5.769 .830 & 204,38 & 6.022 .704 & 104,38 \\
\hline 4 & April & 5.902 .012 & 5.667 .930 & 104,13 & 234.082 & 4,13 \\
\hline
\end{tabular}




\begin{tabular}{|c|c|c|c|c|c|c|}
\hline 5 & Mei & 2.951 .006 & 5.667 .930 & 52,06 & -2.716 .924 & $-47,94$ \\
\hline 6 & Juni & 1.475 .503 & 5.091 .250 & 28,98 & -3.615 .747 & $-71,02$ \\
\hline 7 & Juli & 737.752 & 4.762 .720 & 15,49 & -4.024 .968 & $-84,51$ \\
\hline 8 & Agustus & 368.876 & 4.715 .210 & 7,82 & -4.346 .334 & $-92,18$ \\
\hline 9 & September & 184.438 & 4.817 .110 & 3,83 & -4.632 .672 & $-96,17$ \\
\hline 10 & Oktober & 92.219 & 5.564 .590 & 1,66 & -5.472 .371 & $-98,34$ \\
\hline 11 & November & 46.109 & 7.015 .290 & 0,66 & -6.969 .181 & $-99,34$ \\
\hline 12 & Desember & 23.055 & 7.528 .280 & 0,31 & -7.505 .225 & $-99,69$ \\
\hline & Jumlah & 31.372 .317 & 69.566 .500 & 45,10 & -38.194 .183 & $-54,90$ \\
\hline \multicolumn{7}{|c|}{ sub DAS Keduang } \\
\hline 1 & Januari & 85.981 .258 & 58.568 .244 & 146,81 & 27.413 .014 & 46,81 \\
\hline 2 & Februari & 82.837 .547 & 38.692 .275 & 214,09 & 44.145 .272 & 114,09 \\
\hline 3 & Maret & 62.272 .688 & 32.509 .073 & 191,55 & 29.763 .615 & 91,55 \\
\hline 4 & April & 43.128 .092 & 31.907 .182 & 135,17 & 11.220 .910 & 35,17 \\
\hline 5 & Mei & 21.564 .046 & 31.907 .182 & 67,58 & -10.343 .136 & $-32,42$ \\
\hline 6 & Juni & 10.782 .023 & 28.652 .840 & 37,63 & -17.870 .817 & $-62,37$ \\
\hline 7 & Juli & 5.391 .012 & 26.818 .634 & 20,10 & -21.427 .622 & $-79,90$ \\
\hline 8 & Agustus & 2.695 .506 & 26.576 .673 & 10,14 & -23.881 .167 & $-89,86$ \\
\hline 9 & September & 1.347 .753 & 27.178 .564 & 4,96 & -25.830 .811 & $-95,04$ \\
\hline 10 & Oktober & 11.353 .831 & 31.404 .623 & 36,15 & -20.050 .792 & $-63,85$ \\
\hline 11 & November & 36.450 .254 & 57.272 .100 & 63,64 & -20.821 .846 & $-36,36$ \\
\hline 12 & Desember & 74.723 .879 & 61.123 .829 & 122,25 & $13.600,050$ & 22,25 \\
\hline & Jumlah & 438.527 .889 & 452.611 .219 & 96,89 & -14.083 .330 & $-3,11$ \\
\hline
\end{tabular}

Sumber: Hasil Perhitungan

\section{Kebutuhan Air}

Perhitungan kebutuhan air ini didasarkan pada kebutuhan pada pola penggunaan lahan yang terdiri dari: lahan tegal, sawah, pemukiman, dan hutan. Dalam perhitungan satuan $\mathrm{mm}$ dikonversikan dalam $\mathrm{m}^{3}$, dengan mengubah satuan $\mathrm{mm}$ menjadi $\mathrm{m}$ (dibagi 1.000) dan mengubah satuan luas dari ha menjadi $\mathrm{m}^{2}$ (dikalikan 10.000), sehingga untuk mengubah satuan $\mathrm{mm}$ menjadi $\mathrm{m}^{3}$ cukup mengalikan $10 \mathrm{X}$ luas penggunaan lahan (ha). Hasil perhitungan ketersediaan dan kebutuhan air permukaan disajikan pada Tabel 4 dan Gambar 1, 2, 3 , dan 4.

\section{Persediaan Air}

Persediaan air di sub DAS Temon pertahun adalah $35.435 .875 \mathrm{~m}^{3}$, sedangkan kebutuhannya adalah $51.053 .247 \mathrm{~m}^{3}$, sehingga persediaan air yang digunakan untuk memenuhi kebutuhan hanya $69,41 \%$, kekurangannya sebesar $15.617 .372 \mathrm{~m}^{3}$ $(30,59 \%)$. Kekurangan air tersebut terjadi pada bulan Januari, Mei - Desember, berkisar 1,51 - 99,24\% dan tertinggi terjadi pada bulan November sebesar 99,24\% dengan persediaan air yang hanya 44.326 $\mathrm{m}^{3}$ dan kebutuhan yang digunakan $5.841 .317 \mathrm{~m}^{3}$, sehingga pada bulan tersebut perlu diupayakan kekurangannya. 


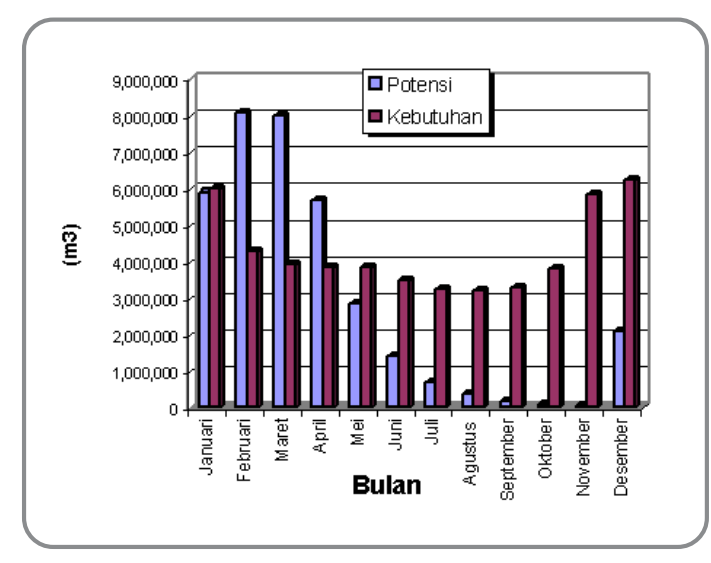

Sumber: Hasil Perhitungan

Gambar 1. Grafik Potensi dan

Kebutuhan Air DAS Temon

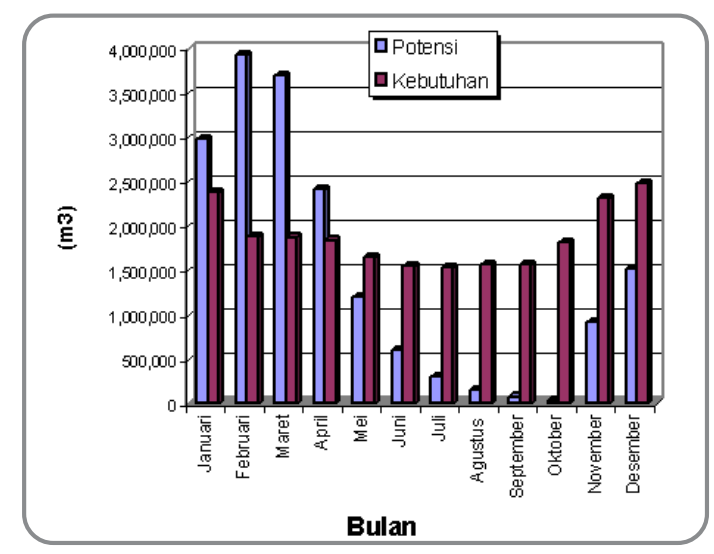

Sumber: Hasil Perhitungan

Gambar 2. Grafik Potensi dan

Kebutuhan Air DAS Wuryantoro

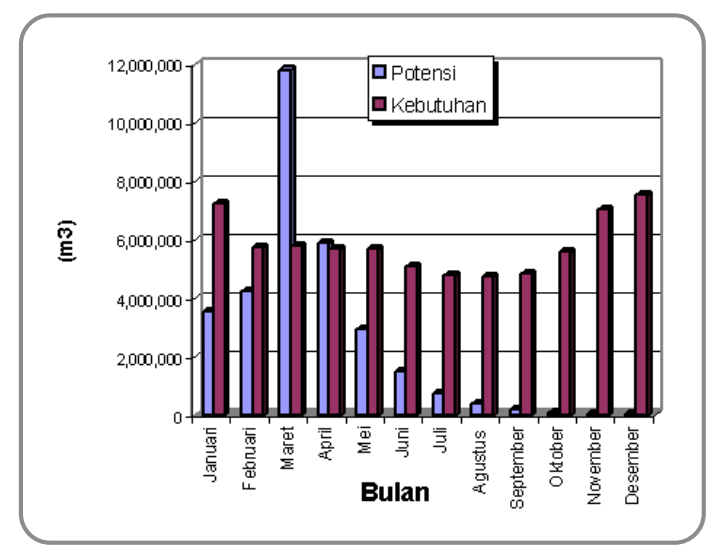

Sumber: Hasil Perhitungan

Gambar 3. Grafik Potensi dan

Kebutuhan Air DAS Alang

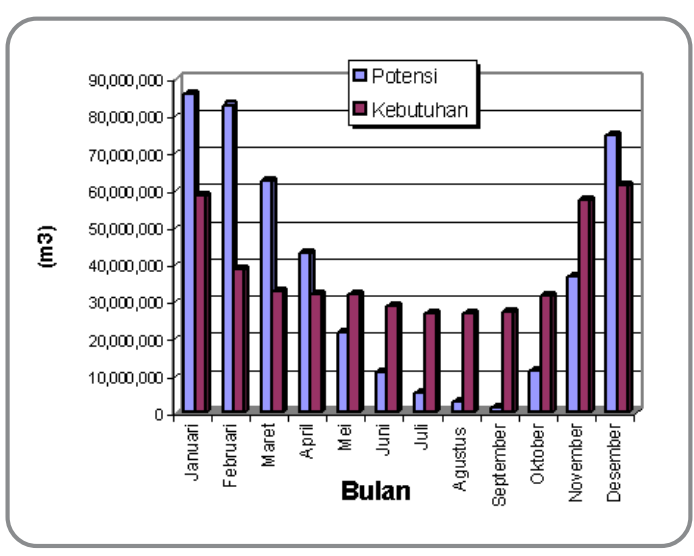

Sumber: Hasil Perhitungan

Gambar 4. Grafik Potensi dan Kebutuhan Air DAS Keduang

Persediaan air di sub DAS Wuryantoro pertahun adalah 17.778.417 $\mathrm{m}^{3}$, sedangkan kebutuhannya adalah $22.413 .430 \mathrm{~m}^{3}$, sehingga persediaan air yang digunakan untuk memenuhi kebutuhan sebesar 79,36\% kekurangannya sebesar 4.625.013 $\mathrm{m}^{3} \quad(20,64 \%)$. Kekurangan air tersebut terjadi pada bulan Mei - November berkisar 27,17\% $97,92 \%$, terting gi terjadi pada bulan Oktober sebesar $97,92 \%$ dengan persediaan air yang hanya $37.585 \mathrm{~m}^{3}$ dan kebutuhan yang digunakan $1.806 .340 \mathrm{~m}^{3}$, sehingga pada bulan tersebut perlu diupayakan kekurangannya.

Persediaan air di sub DAS Alang pertahun adalah $31.372 .317 \mathrm{~m}^{3}$, sedangkan kebutuhannya adalah $69.566 .500 \mathrm{~m}^{3}$, sehingga persediaan air yang digunakan untuk memenuhi kebutuhan hanya $45,10 \%$, kekurangannya sebesar $38.194 .183 \mathrm{~m}^{3}$ (54,90\%). Kekurangan air tersebut hampir merata setiap bulan yaitu pada bulan: Januari, Februari, Mei, Juni, Juli,Agustus, September, Oktober, Nopember, dan Desember berkisar dari $26,07 \%$ - 99,69\% hanya bulan Maret dan 
April saja yang terjadi kelebihan (surplus air), tertinggi terjadi pada bulan Desember sebesar 99,69\% dengan persediaan air yang hanya $23.055 \mathrm{~m}^{3}$ dan kebutuhan yang digunakan $7.508 .280 \mathrm{~m}^{3}$, sehingga pada bulan tersebut perlu diupayakan kekurangannya.

Persediaan air di sub DAS Keduang pertahun adalah $438.527 .889 \mathrm{~m}^{3}$, sedangkan kebutuhannya adalah $452.611 .219 \mathrm{~m}^{3}$, sehingga persediaan air yang digunakan untuk memenuhi kebutuhan sebesar 96,89\%, kekurangannya sebesar $14.083 .330 \mathrm{~m}^{3}$ (3,11\%). Kekurangan air tersebut terjadi pada bulan Mei - November berkisar 32,42\% - 95,04\%, tertinggi terjadi pada bulan September sebesar $95,04 \%$ dengan persediaan air yang hanya $1.347 .753 \mathrm{~m}^{3}$ dan kebutuhan yang digunakan $27.178 .504 \mathrm{~m}^{3}$, sehingga pada bulan tersebut perlu diupayakan kekurangannya.

\section{KESIMPULAN}

1. Persediaan air pertahun di sub DAS Temon sebesar 1.684.246 $\mathrm{m}^{3}$ dan kebutuhan sebesar $2.334 .744 \mathrm{~m}^{3}$, sehingga kekurangan air sebesar $27,86 \%$ pertahun terjadi pada bulan April sampai dengan Desember berkisar 26,07\% - 99,69\% .

2. Persediaan air di sub DAS Wuryantoro sebesar 17.788.417 $\mathrm{m}^{3}$ dan kebutuhan sebesar $22.413 .430 \mathrm{~m}^{3}$, sehingga kekurangan air 20,64\% pertahun terjadi pada bulan Mei sampai dengan November berkisar 27,17\%-97,92\%. Untuk mengatasi kekurangan air pada sub DAS Temon dan Wuryantoro yang merupakan formasi geologi campuran campuran volkan tua-kapur yaitu: (1) Perlu dikembangkan teknik-teknik penyimpanan air dengan membuat sumur-sumur resapan baik pada lahan pemukiman maupun pada lahan tegalan; dan (2) Menjaga kelestarian tanah dan sumber-sumber air di daerah hulu.

3. Persediaan air pertahun pada sub DAS Alang sebesar $31.372 .317 \mathrm{~m}^{3}$ dan kebutuhan sebesar $69.566 .500 \mathrm{~m}^{3}$, sehingga kekurangan air sebesar $54,90 \%$ pertahun terjadi pada bulan Januari, Februari dan Mei - Desember berkisar 26,07\% - 99,69\%. Untuk mengatasi kekurangan air pada sub DAS yang merupakan formasi geologi kapur yaitu: (1) Perlu dikembangkan sumber-sumber air dengan sistem perencanaan yang baik mencakup penyusunan rencana pembangunan, rencana pemanfaatannya dan rencana penggunaan air dengan memperhatikan berbagai keperluan menurut prioritas yang ditentukan; (2) Pengembangan pemanfaatan air tanah pada daerah yang dimungkinkan; (3) Pembangunan konservasi air (embung); dan (4) Menjaga kelestarian tanah dan sumber-sumber air di daerah hulu.

4. Persediaan air pertahun sub DAS Keduang sebesar $438.527 .889 \mathrm{~m}^{3}$ dan kebutuhan sebesar 452.611.219 $\mathrm{m}^{3}$, sehingga kekurangan air sebesar $3,11 \%$ pertahun terjadi pada bulan Mei sampai dengan November berkisar 32,42\% - 95,04\%. Untuk mengatasi kekurangan air yang relatif kecil pada sub DAS ini yang merupakan formasi geologi volkan muda yaitu: (1) Perlu dijaga bangunan prasarana pengairan dan konservasi air yang telah dibangun agar dapat berfungsi terus-menerus; dan (2) Menjaga kelestarian tanah dan sumber-sumber air di daerah hulu. 


\section{DAFTAR PUSTAKA}

Anna, Alif Noor, Retno Woro Kaeksi, dan Yuli Priyana. 2000. Pola Konsumsi Air Untuk Kebutuhan Rumah Dan Faktor-faktor Yang Mempengaruhinya Di Banyudono Kabupaten Boyolali, Forum Geografi No : 26/XIV/Juli/2000.

Asdak, C. 1995. Hidrologi dan Pengelolaan Daerah Aliran Sungai. Yogyakarta: Gadjah Mada University Press.

Balai Teknologi Pengelolaan Daerah Aliran Sungai Surakarta (BTPDAS), 2001. Analisis Neraca Air Untuk Penetapan Kesesuaian Tanaman Pinus Merkusii Di PT Perbutani (Persero) Unit I Jawa Tengah. Kerjasama antara PT Perhutani (Persero) Unit I Jawa Tengah dengan BTP DAS Surakarta.

Budi Pramono, I. 2001. Pedoman Teknis Perbitungan Neraca Air Dengan Metode Thornthwaite Mather. Info DAS Nomor 11 Tahun 2001. Balai Teknologi Pengelolaan DAS Surakarta

Dumairi. 1992. Ekonomika Sumber daya Air. Pengantar ke Hidronamika, BPFE. Yogyakarta.

Hadi, Pramono. 2006. Pemahaman Karakteristik Hujan Sebagai Dasar Pemilihan Model Hidrologi (Studi Kasus di DAS Bengawan Solo Hulu), Forum Geografi Vol.20, No.1, Juli 2006.

Pereira, H.C. 1967. Effects of Landuse On Water And Energy Budgest Of TropicalW aters he ds. International Symposium on Forest Hydrology, Pergamon Press, NewYork.

Soewarno dan Srimulat Yuningsih. 2000. Karakteristik Hidrologi Daerah Pengaliran Sungai Garang, Forum Geografi No : 26/XIV/Juli/2000.

Thornthwaite, C.W. and J.R. Mather. 1957. Instruction and Tabels For Computing Potensial Evapotransprration And Water Balance . Publication in Climatology Drexel Institute of Technology, Laboratory of Climatology 